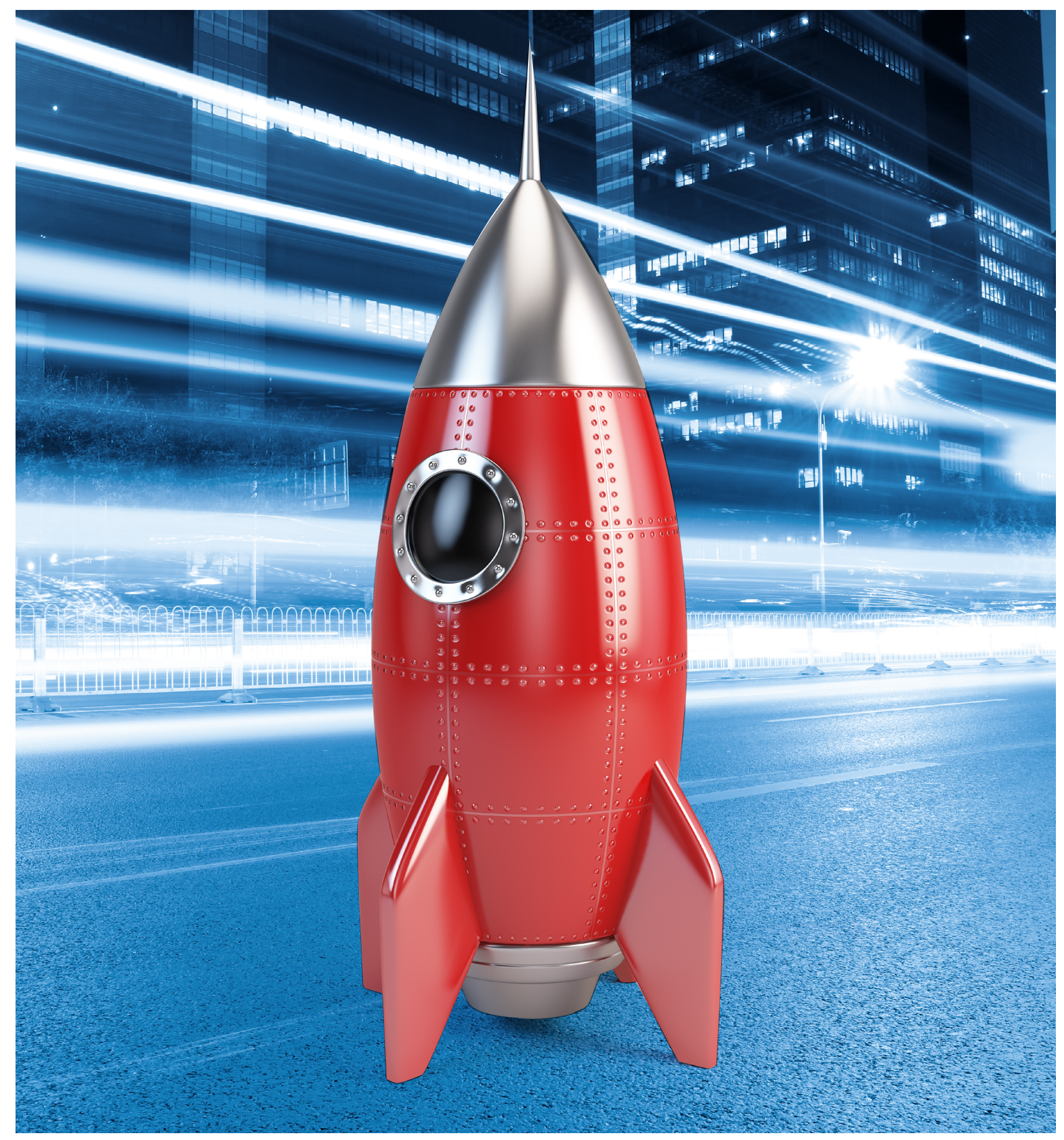

\title{
NOVOS NEGÓCIOS E EMPREENDEDORISMO
}




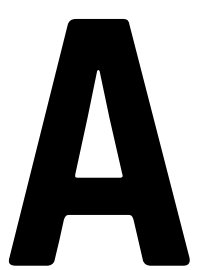

$G$-executivo, publicação da Fundação Getulio Vargas (FGV), vem conquistando cada vez mais leitores entre o público executivo. Desde o ano passado, a revista ganhou roupagem nova e tem publicado pesquisas aplicadas de administração. Vários temas já foram tratados: varejo, finanças e controladoria, saúde, sustentabilidade, tecnologia de informação, sempre com a participação de professores da FGV EAESP, pesquisadores dos centros de estudo e a contribuição de executivos, com foco em soluções práticas e na antecipação de cenários nos mais diversos setores no país.

O Caderno Especial desta edição é dedicado ao empreendedorismo. Tanto teórica quanto praticamente, o empreendedorismo tem cada vez mais despertado a atenção de pesquisadores e de diversos setores econômicos, seja por trazer soluções tecnológicas inovadoras que reorganizam o mercado, seja por apontar novas perspectivas para velhos problemas. Na sociedade brasileira, o empreendedorismo está em alta por diversos fatores, como ajudar na criação de renda num cenário recessivo e de desemprego, possibilitar formas mais flexíveis de trabalho para jovens que não se interessam pelas carreiras tradicionais nas grandes empresas, permitir a conciliação de trabalho e família para mulheres, e, no caso do empreendedorismo social, buscar modelos inovadores na base da pirâmide. Para alguns, o empreendedorismo pode ser uma oportunidade; para outros, pura sobrevivência. Mas nem todos conseguem a salvação com novos negócios. É preciso, com o ensino do empreendedorismo, tornar essa atividade menos sonho e mais profissional.

Neste Caderno Especial, Gilberto Sarfati mostra a dinâmica de aportes de quem investe em startups. Investidores-anjo e aceleradoras, que até há pouco davam suporte nos estágios iniciais dos empreendimentos, passaram a colocar recursos apenas após o modelo de negócio ter se provado viável. Edgard Barki e Laura Pansarella apresentam como o empreendedorismo social que nasce nas "margens" busca romper com a lógica de um movimento originalmente da elite para a base e traz soluções inovadoras da periferia para o centro. $\mathrm{O}$ empreendedorismo corporativo também cresce no Brasil (e no mundo), e Marcus Alexandre Yshikawa Salusse e Newton Monteiro de Campos Neto exploram como melhor aproveitar essas oportunidades. Maria José Tonelli e Tales Andreassi revelam que o caminho do empreendedorismo feminino não é fácil de trilhar, e, embora os negócios criados por mulheres venham crescendo no Brasil, eles têm taxa de mortalidade maior do que aqueles criados por homens. Na área do empreendedorismo cultural, Adriana Miguel Ventura argumenta que o empreendedor artístico e cultural precisa quebrar a dependência de grandes projetos e verbas de incentivo do modelo atual.

Além dos artigos do Caderno Especial, outros trabalhos completam esta edição: Luiz Migliora Neto mostra que o Brasil precisa melhorar seu processo de defesa comercial para combater o dumping de aço chinês e, assim, estabelecer uma cadeia vertical de produção industrial. José Renato Salles, Thomaz Wood Jr. e Miguel Caldas retomam a questão controversa da mudança cultural e afirmam que, há quatro décadas, acadêmicos e consultores vêm criando e aplicando receitas para mudar a cultura organizacional. Entretanto, muitos processos falham, frustrando seus líderes. No artigo, eles sugerem caminhos para mudanças bem-sucedidas. Finalmente, Benjamin Rosenthal, Eliane Brito e Magali Coelho discutem se a mídia tradicional deve ficar ou sair das redes sociais. Permanecer significa ter maior difusão do conteúdo; sair, por outro lado, diminui o risco de que as notícias sejam usadas de forma a prejudicar a reputação. Esse é um dilema não só para jornais e revistas, mas também para todas pessoas e empresas em tempos de mídias sociais.

A edição ainda conta com a coluna Fora da Caixa, Me engana que eu gosto, de Samy Dana; a coluna Economia, A privatização não vai salvar a pátria, de Paulo Sandroni; a coluna Sociedade e Gestão, que trata de um tema quente nesse momento da sociedade brasileira: Eleições 2018: sob o signo da incerteza e da continuidade, de Marco Antonio Carvalho Teixeira; e com a coluna Tecnologia, O blockchain veio para ficar, de Eduardo Diniz.

No espírito do tema do Caderno Especial, a entrevista com o empreendedor Thomaz Srougi, fundador do Dr.Consulta, revela o que pensa o criador desse modelo de negócio emergente na saúde, que pretende ser uma alternativa tanto ao sistema público quanto aos planos de saúde.

Gostaríamos de receber comentários de nossos leitores sobre o conteúdo que a $G V$-executivo tem veiculado. Para isso, entre em contato conosco por meio do e-mail: gvexecutivo@fgv.br.

Desejamos a todos uma ótima leitura!

Maria José Tonelli - Editora chefe

Adriana Wilner - Editora adjunta 